\title{
Passive Seat Suspension With a Vibration Absorber
}

Štefan Segl'a ${ }^{1}$, Martin Orečný ${ }^{1}$, Nataša Trišović ${ }^{2}$

${ }^{1}$ Faculty of Mechanical Engineering, TU of Košice

2Faculty of Mechanical Engineering, Belgrade University

The paper deals with modelling and optimization of a working machine seat suspension system parameters. Experimental work in the past shown that it is possible to replace even more complicated, for example parallelogram or scissor mechanisms, with simpler dynamic models of 1 or 1.5 degree of freedom (Zener model). The optimization of stiffness and damping parameters is realized using multiobjective function. The first component of the function expresses the acceleration of the seat squab, this points on the comfort of the seat, the second one expresses the relative displacement of the seat squab in regard to the working machine cabin, points on the better operator's sightedness and safe handling of the machine. This optimization process allows to propose so called „soft“", „medium", or „hard" seat suspensions according to the value of the weighting coefficient. The paper also points on the possibility of improving the dynamic characteritics of the seat with the use of a vibration absorber. The expediency of its application is especially in working machines without significant changes in the seat excitation frequency spectrum.

Keywords: passive seat suspension, vibration absorber, modelling, optimization, frequency spectrum

\section{Acknowledgement}

This work was supported by grant project VEGA No. 1/1205/12.

\section{References}

[1] Optimization Toolbox for use with MATLAB. Users guide, Version 2. Natick (USA): The Mathworks Inc., 2004. p. 152. ISBN 0-13-272550-9.

[2] JAVOŘÍK, Jakub; MAŇAS, Miroslav. Tvarová optimalizace pryžové manžety. Strojirrenská technologie, 2011, roč. XVI, č. 1, s. 21-27. ISSN 1211-4162.

[3] KALKER-KALKMAN, Cornelia M.; SEGLA, Stefan. Optimization and comparison of trailer suspension systems. Engineering Mechanics. 2000, Vol. 7, No. 6, p. 121-134. ISSN 1802-1484.

[4] PETŘíČEK, Jiř́i. Vibroizolace sedačky řidiče důlniho stroje pomocí dynamického absorbéru kmitů. Diplomová práce. Liberec: FS TU Liberec, 2010. $65 \mathrm{~s}$.

[5] SÁGA, M. et al. Vybrané metódy analýzy a syntézy mechanických sústav. Žilina: VTS ŽU v Žiline, 2009. 360 s. ISBN 978-80-89276-17-2.

[6] STEIN, Juraj G.; MÚČKA, Peter; GUNSTON, Tom P. A study of locomotive driver's seat vertical suspension system with adjustable damper. Vehicle System Dynamics. 2009, Vol. 47, No. 3, p. 363-386. ISSN 0042-3114.

[7] NAD, Milan. Analysis of modal properties of beam structural elements with reinforcing core. Machine Dynamics Research. 2010, Vol. 34, No. 4, p. 53-61. ISSN 2080-9948. 